\title{
Using of 2,7-Dihydroxynaphthalene as a Novel Reagent in Spectrophotometric Assay of Chloramphenicol
}

\author{
Sudad R. Jamal \\ Nabeel S. Othman \\ Department of Chemistry/ College of Science/ University of Mosul
}

(Received 16/8/2018; Accepted 25/10/2018)

\begin{abstract}
An indirect spectrophotometric method for the determination of chloramphenicol (CAP) has been suggested. The method is based on the oxidative coupling reaction of reduced chloramphenicol (R-CAP) with 2,7- dihydroxynaphthalene (2,7-DHN) reagent in the presence of potassium dichromate as oxidizing agent to produce brown colored, stable and soluble product. This product showed maximum absorption at $544 \mathrm{~nm}$. Beer's law is obeyed over the range 0.57.5. $\mu \mathrm{g} . \mathrm{ml}^{-1}$ of R - CAP and molar absorptivity of $1.069 \times 10^{5} 1 . \mathrm{mol}^{-1} . \mathrm{cm}^{-1}$ and Sandell's sensitivity index of $0.0030 \mu \mathrm{g} . \mathrm{cm}^{-2}$, limit of detection (LOD), limit of quantitation (LOQ), relative error (RE\%) and relative standard deviation (RSD\%) have been estimated. The method has been successfully applied to the determination of CAP in drug formulations.
\end{abstract}

Keywords: chloramphenicol, 2,7- dihydroxynaphthalene, spectrophotometry, oxidative coupling.

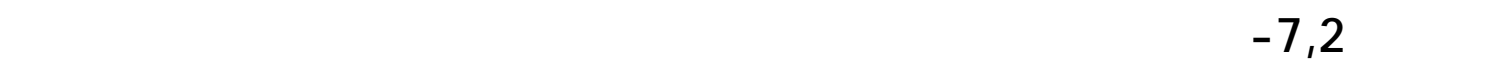

\author{
الملغص

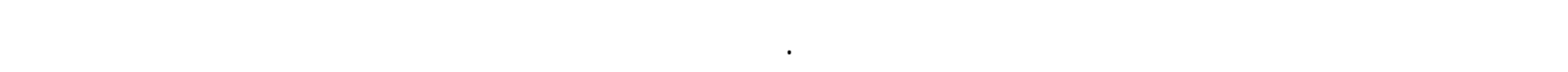 \\ الكلورالمفينيكول المختزل والكلثف 2 - ثنائي هيدروكسيل الفثالين بوجود العلمل المؤكسد ثنائي كروملت البوتلسيوم لتكوين

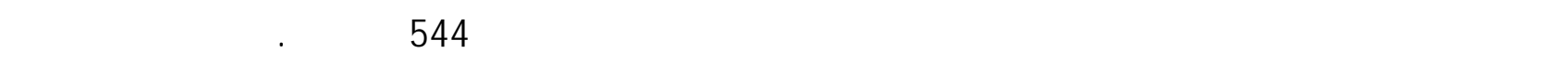

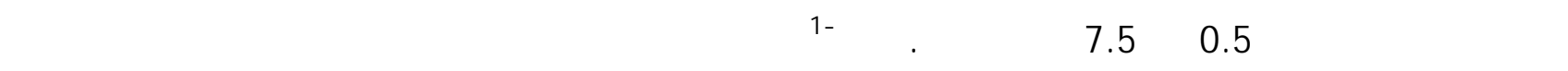

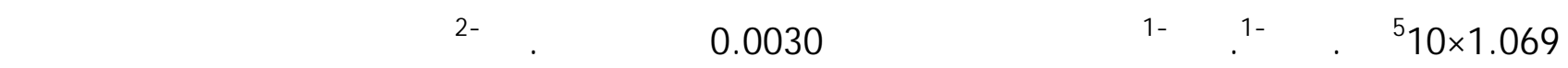 \\ (LOD) والقدير الكمي (LOQ) والغطأ النبب (RE\%) والانحرف القيلسي (RSD\%). وطُقت الطريقة المقترحة بنجاح \\ لقدير الكلورلمفينيكول في المستحضرات الدوائية.
}

الكلمات الدالة: 2،7 -ثنائي هيدروكسيل الفثالين،طيفي، الاقتران التلكسدي.

\section{INTRODUCTION}

Chloramphenicol,a broad spectrum antibiotic is first isolated from cultures of Streptomycest, and is effective against a wide variety of Gram-positive and Gram-negative bacteria. It is widely used because it is inexpensive and readily available (Falagas et al., 2008). Chloramphenicol is 2,2dichloro-N-[(1R,2R)-2-hydroxy-1-(hydroxymethyl)-2-(4-nitrophenyl) ethyl] acetamide, produced by the growth of certain strains of Streptomyces venezuelae in a suitable medium. It is normally prepared by synthesis. It contains no less than 98.0 and not more than the equivalent of $102.0 \%$ of $\mathrm{C}_{11} \mathrm{H}_{12} \mathrm{Cl}_{2} \mathrm{~N}_{2} \mathrm{O}_{5}$, calculated with reference to the dried substance. CAP is a white, greyish-white or yellowish-white, fine, crystalline powder or fine crystals, needles or elongated plates, slightly soluble in water, freely soluble in alcohol and in propylene glycol, and has the following structure (British Pharmacopeia, 2013). 


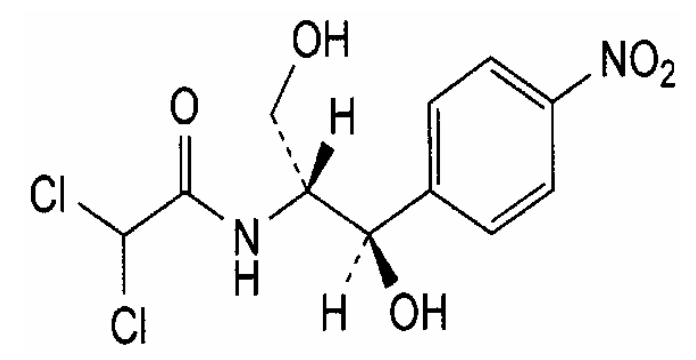

CAP structure, M.wt $=323.1322 \mathrm{~g} / \mathrm{mol}$

For the determination of studied drug, various methods have been reported in literature; these methods included: High performance liquid chromatography (HPLC) which is one of the most powerful and versatile tool for the quantitative determination of CAP (Hoang et al., 2015; Suguna et al., 2014; Mallu et al., 2011), also LC-MS (Bjorn, 2013), LC-MS-MS (Rocha et al., 2015). Other analytical methods have been reviewed in literature these methods included: voltammetry (Yafeng et al., 2014), Polarography (Suliman and Razzak, 2000), so that various spectrophotometric methods have been used (Alshirifi and Alhameedi, 2016; Suguna et al., 2016; Wafi et al., 2015; Al-Abachi et al., 2014; Al-Sabha and Al-Hammoshi, 2013; Sinan and Al-Abachi, 2010; Sayhood et al., 2013; Al-Sabha and Rasheed, 2010; Al-Ward, 2012).

The aim of the present work is to provide a sensitive, simple and accurate indirect spectrophotometric method to the determination of CAP in its drug formulations.

\section{Apparatus}

\section{EXPERIMENTAL}

A JASCOV - $630 \mathrm{UV} / \mathrm{V}$ spectrophotometer (Japan), with $1 \mathrm{~cm}$ matched quartz cells were used for all measurements. $\mathrm{pH}$ measurements have been done by HANNA $211 \mathrm{pH}-\mathrm{meter}$. The balance BEL ENGNEERING was used in the weighing process.

\section{Reagents}

All chemicals used in this investigation are of analytical - reagent grade, and CAP standard material was provided from General Establishment for Medical Appliance and Drugs/ SDI Samaraa/ Iraq.

\section{Solutions}

\section{2,7- dihydroxynaphthalene $(0.005 \mathrm{M})$}

This solution was prepared by dissolving $0.0400 \mathrm{~g}$ of 2,7- dihydroxynaphthalene (Fluka) in $50 \mathrm{ml}$ distilled water.

\section{Reduced - CAP(R-CAP) Solution (500 $\left.\mu \mathrm{g} \cdot \mathrm{ml}^{-1}\right)$.}

This solution was attended by dissolving $0.0500 \mathrm{~g}$ of pure CAP in $50 \mathrm{ml}$ ethanol, then transfer the solution to beaker size $125 \mathrm{ml}$ and $20 \mathrm{ml}$ of distilled water, $20 \mathrm{ml}$ of hydrochloric acid (1 M ) and $3 \mathrm{~g}$ of zinc powder were added, mixed well and allowed to stand for $1 \mathrm{hr}$ at the temperature of the laboratory. Then the residue filtered and wash the residue with distilled water into a $100 \mathrm{ml}$ volumetric flask then the volume completed to mark with distilled water to prepare a solution at a concentration of $500 \mu \mathrm{g} \cdot \mathrm{ml}^{-1}\left(1.547 \times 10^{-3} \mathrm{M}\right)$ of R-CAP. More diluted solutions were prepared daily by appropriate dilution using distilled water (Al-Abachi and Abed, 2014) .

\section{Reduced - CAP(R-CAP) Solution $\left(50 \mu \mathrm{g} \cdot \mathrm{ml}^{-1}\right)$.}

This solution was prepared by taking $5 \mathrm{ml}$ of Reduced - CAP(R-CAP) solution $\left(500 \mu \mathrm{g} \cdot \mathrm{ml}^{-1}\right)$ and then diluted to $50 \mathrm{ml}$ with distilled water in a volumetric flask.

\section{Potassium Dichromate (0.005 M)}

This solution was prepared by dissolving $0.0735 \mathrm{~g}$ of potassium dichromate (Fluka) in $50 \mathrm{ml}$ distilled water in a volumetric flask.

\section{Solutions of Pharmaceutical Preparations:}

\section{1- Phenicol Eye Drop}

The contents of three bottles of eye drops were mixed. An aliquot corresponding to $50 \mathrm{mg}$ of CAP $(10 \mathrm{ml})$ was diluted to $50 \mathrm{ml}$ with ethanol in a volumetric flask. This solution was 
transferred into $125 \mathrm{ml}$ beaker and was proceeded as mentioned above in the preparation of R-CAP $\left(50 \mu \mathrm{g} \cdot \mathrm{ml}^{-1}\right)$ ( Al-Abachi and Abed, 2014).

2- Chloramphenicol Capsules

Weight the contents of 5 capsules (each one contain $250 \mathrm{mg}$ of CAP). An accurately weighed amount of powder( $0.0603 \mathrm{~g})$ equivalent to $50 \mathrm{mg}$ CAP was dissolved in $50 \mathrm{ml}$ ethanol in a volumetric flask, then the solution was transferred into $125 \mathrm{ml}$ beaker and was proceeded as mentioned above in preparation of R-CAP $\left(50 \mu \mathrm{g} \cdot \mathrm{ml}^{-1}\right)$ (Al-Abachi and Abed, 2014).

3- Injection

The contents of 3 vials were mixed, a 0.073 g equivalent to $50 \mathrm{mg}$ CAP was dissolved in 50 $\mathrm{ml}$ ethanol in a volumetric flask then the solution was transferred into $125 \mathrm{ml}$ beaker and was proceeded as mentioned above in preparation of R-CAP (50 $\left.\mu \mathrm{g} \cdot \mathrm{ml}^{-1}\right)$ (Al-Abachi and Abed, 2014).

Procedure and Calibration Graph

To a series of $10 . \mathrm{ml}$ calibrated flasks, transferred $0.1-1.5 \mathrm{ml}$ of $50 \mathrm{ppm}$ of R-CAP, then 2.0 $\mathrm{ml}$ of 2,7-DHN solution $(0.005 \mathrm{M})$ and $2.5 \mathrm{ml}$ of potassium dichromate solution $(0.005 \mathrm{M})$ were added, after dilution to the mark with ethanol. The absorbance was measured at 544 against the blank. A linear calibration graph was obtained over the concentration range from 0.5 to $7.5 \mu \mathrm{g} \cdot \mathrm{ml}^{-1}$ (Fig. 1).

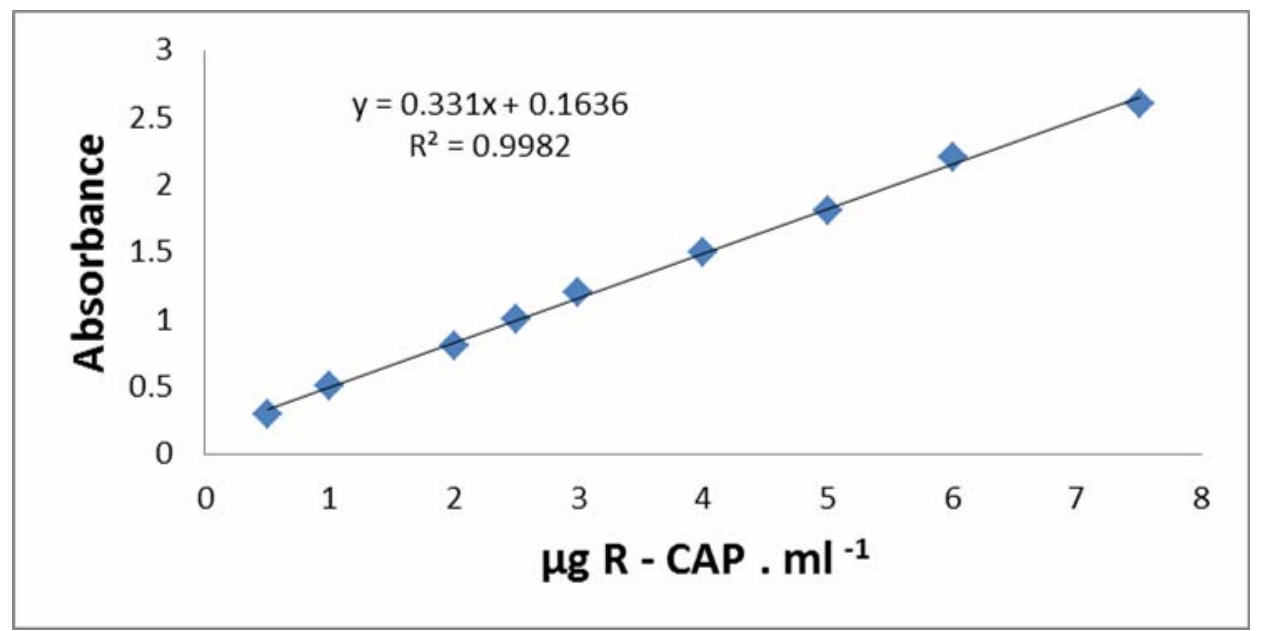

Fig. 1: Calibration graph for R-CAP determination

\section{Optical and Regression Characteristics of the Present Method}

The molar absorptivity, Sandell's sensitivity, the limits of detection (LOD) and limit of quantitation (LOQ) were given in (Table 1) which indicated good sensitivity of the suggested method.

Table 1: Optical and regression characteristics of the present method

\begin{tabular}{|c|c|}
\hline Parameter & Value \\
\hline Beer's law $\left(\mu \mathrm{g} . \mathrm{ml}^{-1}\right)$ & $0.5-7.5$ \\
\hline$\lambda_{\max },(\mathrm{nm})$ & 544 \\
\hline Molar absorptivity $1 . \mathrm{mol}^{-1} . \mathrm{cm}^{-1}$ & $1.069 \times 10^{5}$ \\
\hline Linear regression equation & $\mathrm{Y}=\mathrm{ax} *+\mathrm{b}$ \\
Slope $=\mathrm{a}$ & 0.331 \\
Intercept $=\mathrm{b}$ & 0.1636 \\
\hline Determination coefficient $\left(\mathrm{R}^{2}\right)$. & 0.9982 \\
\hline Relative standard deviation. & Not more than $0.18 \%$ \\
\hline Limit of detection. $\left(\mu \mathrm{g} \cdot \mathrm{ml}^{-1}\right)$ & 0.00238 \\
\hline Limit of quantitation. $\left(\mu \mathrm{g} \cdot \mathrm{ml}^{-1}\right)$ & 0.00791 \\
\hline * concentration in $\mu \mathrm{g} . \mathrm{ml}^{-1}$ &
\end{tabular}




\section{Principles of the Method}

\section{RESULTS AND DISCUSSION}

The method included 2 steps of reactions:

1- Conversion of CAP to reduced - CAP ( R-CAP )
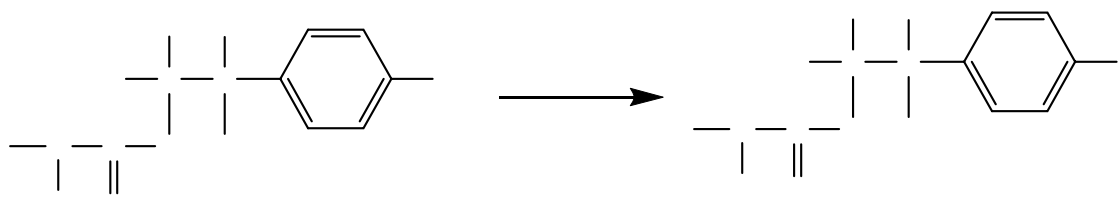

2- Coupling of R-CAP with 2,7-DHN reagent in presence of potassium dichromate.
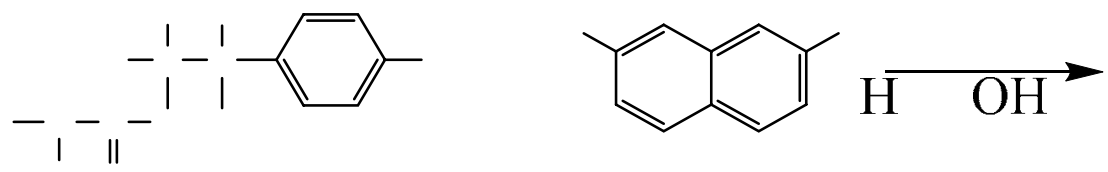

$\mathrm{HOH}_{2} \mathrm{C} \quad \mathrm{C} \quad \mathrm{C}$

Optimization of the Experimental Conditions $\stackrel{\mathrm{C}}{\mathrm{C}} \quad \mathrm{C} \quad \mathrm{NH}$

During the investigation, the $1 \mathrm{ml}$ of R-CAP solution which is equivalent to $50 \mu \mathrm{g} \cdot \mathrm{ml}^{-1} \mathrm{CAP}$ was taken and the final volume was brought to $10 \mathrm{Chl}$ with distilled water.

\section{Effect of 2,7-DHN amount:}

The effect of different amounts of 2,7-DHN solution $(0.005 \mathrm{M})$ on the intensity of the colored product at different amounts $(2.5-7.5 \mu \mathrm{g})$ of R-CAP has been studied. A $2.0 \mathrm{ml}$ of 2,7-

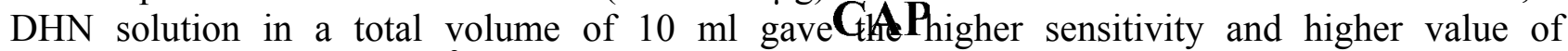
determination coefficient $\left(\mathrm{R}^{2}\right)$; therefore, it has been selected for subsequent experiments (Table 2).

Table 2: Effect of 2,7-DHN amount

\begin{tabular}{|c|c|c|c|c|c|}
\hline \multirow{2}{*}{$\begin{array}{c}\text { Amount of } 0.005 \mathrm{M} \\
\text { 2,7-DHN (ml) }\end{array}$} & \multicolumn{4}{|c|}{ 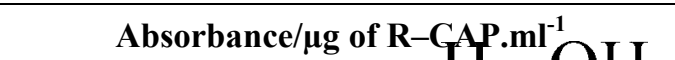 } & \multirow{2}{*}{$\mathbf{R}^{2}$} \\
\hline & 2.5 & 3.75 & 5 & 7.5 & \\
\hline 1 & 0.2397 & H & 0.49 & 0.6269 & 0.9714 \\
\hline 1.5 & 0.2785 & 0.319 & 0.5720 & 0.6900 & 0.9528 \\
\hline 2.0 & 0.311 & 0.48 & .62 & Q.7595 & 0.9738 \\
\hline 2.5 & 0.2837 & 0.407 & 0.5285 & 0.6272 & 0.9719 \\
\hline
\end{tabular}

\section{Choice the Oxidizing Agent}

\section{Cl $\mathrm{O}$}

Several oxidizing agents have been tested $\left(\mathrm{KIO}_{4}, \mathrm{~K}_{2} \mathrm{Cr}_{2} \mathrm{O}_{7}\right.$, N-Bromosuccinimide, $\mathrm{N}$-Chlorosuccinimide ), $\mathrm{K}_{2} \mathrm{Cr}_{2} \mathrm{O}_{7}$ gave the most sensitive reaction. (Table 3).

Table 3: Choice the oxidizing agent

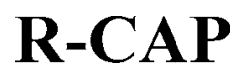

\begin{tabular}{|c|c|c|}
\hline Oxidizing agent $\mathbf{( 0 . 0 0 5 M}, \mathbf{1 m l})$ & $\boldsymbol{\lambda}_{\max .(\mathbf{n m})}$ & Absorbance \\
\hline N-Chlorosuccinimide & \multicolumn{2}{|c|}{ No color contrast } \\
\hline Potassium periodate & 475 & 0.2277 \\
\hline N-Bromosuccinimide & & No color contrast \\
\hline Potassium dichromate & 526 & 0.6205 \\
\hline
\end{tabular}




\section{Effect of Potassium Dichromate Amount}

The effect of potassium dichromate amount on the absorbance has been investigated. The suggested procedure has been carried out with different amounts of $\mathrm{K}_{2} \mathrm{Cr}_{2} \mathrm{O}_{7}$; the high intensity of the colored product was achieved by using $2.5 \mathrm{ml}$ of $\mathrm{K}_{2} \mathrm{Cr}_{2} \mathrm{O}_{7}(0.005 \mathrm{M})$; therefore; it has been selected for the subsequent experiment. (Table 4).

Table 4: Effect of potassium dichromate amount

\begin{tabular}{|c|c|c|c|c|}
\hline \multirow[t]{2}{*}{ Amount of $0.005 \mathrm{M} \mathrm{K}_{2} \mathrm{Cr}_{2} \mathrm{O}_{7}(\mathrm{ml})$} & \multicolumn{4}{|c|}{ 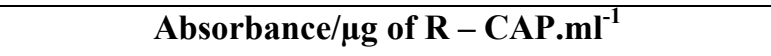 } \\
\hline & 2.5 & 5 & 7.5 & $\mathbf{R}^{2}$ \\
\hline 1 & 0.3106 & 0.6208 & 0.7399 & 0.9685 \\
\hline 2 & 0.6302 & 1.2588 & 1.5092 & 0.9705 \\
\hline 2.5 & 0.9279 & 1.4804 & 1.9596 & 0.9717 \\
\hline 3.0 & 0.8233 & 1.4797 & 1.7499 & 0.9460 \\
\hline
\end{tabular}

\section{Effect of pH}

The effect of $\mathrm{pH}$ on the absorbance has been studied. The result for adding acid ( $\mathrm{HCl}$, $\left.\mathrm{H}_{2} \mathrm{SO}_{4}, \mathrm{CH}_{3} \mathrm{COOH}, 1 \mathrm{M}\right) \mathrm{r}$ base $\left(\mathrm{NaOH}, \mathrm{Na}_{2} \mathrm{CO}_{3}, \mathrm{KOH}, \mathrm{NaHCO}_{3}, 1 \mathrm{M}\right)$ gave unsatisfactory results.

\section{Effect of Surfactant}

The effect of surfactant (SDS, CPC, CETAB, Triton X-100) on absorbance was studied and the results were unsatisfactory. All surfactant used given a turbid solutions. It was therefore not recommended for use in subsequent experiments.

\section{Effect of Temperature}

Some of the oxidative-coupling reactions depended heavily on the degree of temperature, so the reaction was conducted at different temperatures and the results showed that the reaction was not adopted on the temperature significantly, so investigation continued at room temperature (Table 5).

\section{Table 5: Effect of temperature}

\begin{tabular}{|c|c|c|c|c|}
\hline \multirow{2}{*}{$\begin{array}{c}\text { Temperature } \\
\mathbf{C}^{\circ}\end{array}$} & \multicolumn{4}{|c|}{ Absorbance of $\mathbf{5 0} \boldsymbol{\mu} \mathbf{g} \mathbf{R} \mathbf{- C A P}$ in 10 $\mathbf{~ m l} / \mathbf{m i n u t e}$ standing time } \\
\cline { 2 - 5 } $\mathbf{2 0}$ & 1.0953 & 1.1685 & $\mathbf{3 0}$ & $\mathbf{4 0}$ \\
\hline $\mathbf{R T}=\mathbf{2 5}$ & 1.1053 & 1.2799 & 1.3866 & 1.3945 \\
\hline $\mathbf{3 0}$ & 1.1024 & 1.2543 & 1.4785 & 1.4889 \\
\hline $\mathbf{4 0}$ & 1.1013 & 1.2015 & 1.4639 & 1.4745 \\
\hline $\mathbf{5 0}$ & 1.009 & 1.1903 & 1.3575 & 1.4183 \\
\hline
\end{tabular}

\section{Effect of time on the color development}

The effect of the time needed to get full color development has been tested, 30 minutes were found to be optimum time (Table 6).

Table 6: Effect of time on oxidation

\begin{tabular}{|c|c|c|c|c|c|c|c|}
\hline Time, minutes & 5 & 10 & 15 & 20 & 25 & 30 & 40 \\
\hline Absorbance & 1.2144 & 1.2885 & 1.3261 & 1.3873 & 1.4359 & 1.4793 & 1.3983 \\
\hline
\end{tabular}

\section{The stability of Colored Product}

The effect of time on the stability of the color product was studied (Table 7). It was one of the most important problems that faced the work because it is stability in aqueous medium (1) was unsatisfactory, so there have been several attempts to improve the stability, including changing the 
order of addition of the reaction components (2), adding $5 \mathrm{ml}$ of (0.01 M) EDTA solution (3) and using ethanol as a solvent in dilution to the mark (4).

Table 7: The stability of colored product

\begin{tabular}{|c|c|c|c|c|}
\hline \multirow{2}{*}{ Time/min } & \multicolumn{4}{|c|}{ Absorbance of 50 $\boldsymbol{\mu g}$ of R-CAP/ 10 ml } \\
\cline { 2 - 5 } & \multicolumn{3}{|c|}{$\boldsymbol{\lambda}_{\text {max.(nm) }=\mathbf{5 2 6}}$} & $\boldsymbol{\lambda}_{\text {max.(nm) }=\mathbf{5 4 4}}$ \\
\cline { 2 - 5 } & $\mathbf{1 *}$ & $\mathbf{2 * *}$ & $\mathbf{3}$ & $\mathbf{4}$ \\
\hline After dilution & 0.2459 & 1.4420 & 0.0763 & 1.7760 \\
\hline 5 & 0.4693 & 1.4729 & 0.0776 & 1.7784 \\
\hline 10 & 0.7863 & 1.5084 & 0.1180 & 1.7833 \\
\hline 15 & 1.1058 & 1.5574 & 0.1566 & 1.7902 \\
\hline 20 & 1.2873 & 1.5797 & 0.2223 & 1.8002 \\
\hline 25 & 1.3567 & 1.6044 & 0.3208 & 1.8017 \\
\hline 30 & 1.4788 & 1.6100 & 0.5477 & 1.8015 \\
\hline 40 & 1.4893 & 1.6267 & 0.8575 & 1.8014 \\
\hline 50 & 1.5052 & 1.6453 & 1.2215 & 1.8013 \\
\hline 60 & 1.5235 & 1.6542 & 1.3013 & 1.8012 \\
\hline 120 & 1.6011 & 1.6842 & 1.6590 & 1.7707 \\
\hline
\end{tabular}

* $\mathrm{R}-\mathrm{CAP}+2,7-\mathrm{DHN}+\mathrm{K}_{2} \mathrm{Cr}_{2} \mathrm{O}_{7}$

$* * 2,7-\mathrm{DHN}+\mathrm{K}_{2} \mathrm{Cr}_{2} \mathrm{O}_{7}+\mathrm{R}-\mathrm{CAP}$

The results in (Table 7) showed that the fourth treatment gave a better stability of colored product with red shift. Therefore, ethanol and $544 \mathrm{~nm}$ were used in subsequent experiments.

\section{Final Absorption Spectra}

Under the above optimized conditions, absorption spectra of the colored product was formed from the reaction of R-CAP with 2,7-DHN in presence of potassium dichromate against its corresponding reagent blank which showed a maximum absorption at $544 \mathrm{~nm}$., and this wavelength was selected on the subsequent experiments (Fig. 2).

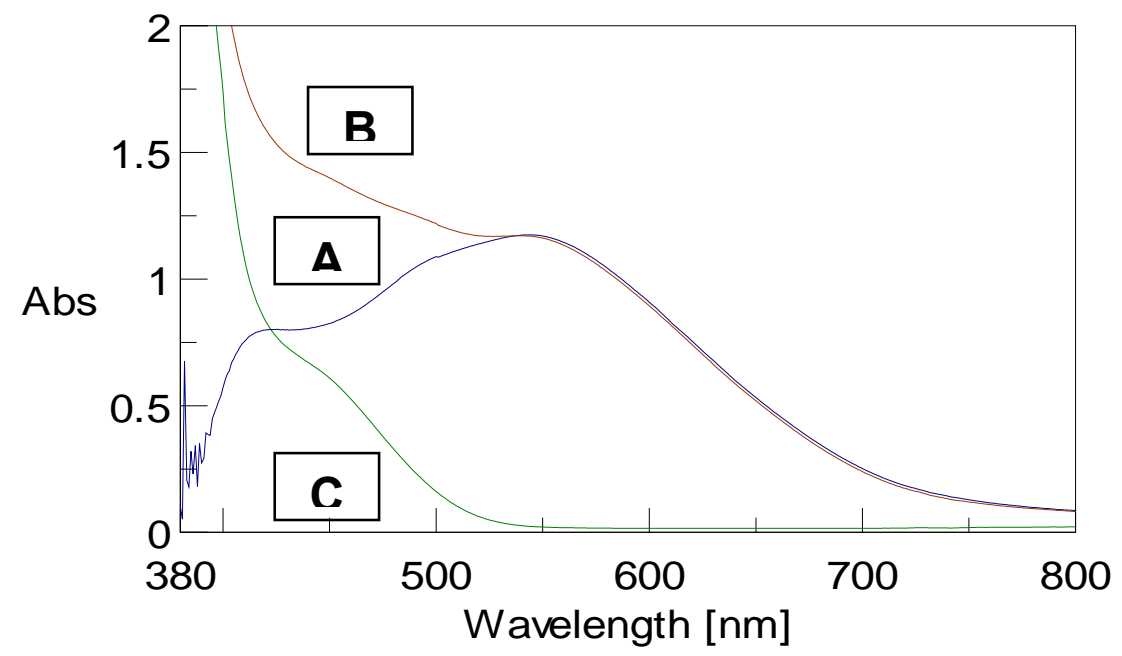

Fig. 2: Absorption spectra of $25 \mu \mathrm{g}$ CAP / $10 \mathrm{ml}$ treated according to the recommended procedure and measured against $(A)$ reagent blank, $(B)$ ethanol and $(C)$ reagent blank measured against ethanol.

\section{Analytical Application}

The proposed method was applied to determine CAP in different drug formulations. On applying proposed procedure, good recovery, accuracy and precision were obtained as shown in (Table 8). 
Table 8: Analytical application

\begin{tabular}{|c|c|c|c|c|c|}
\hline $\begin{array}{c}\text { Pharmaceutical } \\
\text { preparation }\end{array}$ & $\begin{array}{c}\mu \mathrm{g} R \text { - CAP } \\
\text { present } / 10 \mathrm{ml}\end{array}$ & $\begin{array}{c}\mu \mathrm{g} \mathbf{R}-\mathrm{CAP} \\
\text { measured } / 10 \mathrm{ml}\end{array}$ & \% Recovery & RSD \% ${ }^{*}$ & RE \%* \\
\hline \multirow{2}{*}{$\begin{array}{c}\text { PHENICOL } \\
\text { Eye Drop } \\
\text { (Api , Jordan ) }\end{array}$} & 25 & 24.9 & 99.6 & 0.05 & -0.4 \\
\hline & 50 & 50.05 & 100.1 & 0.11 & -0.1 \\
\hline \multirow{2}{*}{$\begin{array}{l}\text { Chloramphenicol } \\
\text { sodium succinate } \\
\text { equivel 1G base } \\
\text { powder vail } \\
\text { (Macleods, India ) }\end{array}$} & 25 & 24.9 & 99.6 & 0.02 & -0.4 \\
\hline & 50 & 49.9 & 99.8 & 0.08 & -0.2 \\
\hline \multirow{2}{*}{$\begin{array}{l}\text { Chloramphenicol } \\
\text { capsules Bp } 250 \mathrm{mg} \\
\text { (Brawn, India ) }\end{array}$} & 25 & 24.9 & 99.6 & 0.18 & -0.4 \\
\hline & 50 & 49.8 & 99.6 & 0.08 & -0.4 \\
\hline
\end{tabular}

*Averge of 5 determination.

\section{CONCLUSION}

The suggested procedure for CAP determination was sensitive, accurate and can be used in the determination of CAP in different types of formulations without extraction or separation.

\section{REFERENCES}

Al-Abachi, M.Q.; Abed, S.S.; Al-Uzri, W.A. (2014). Spectrophotometric determination of chloramphenicol in pharmaceutical preparations. Iraqi Nat. J. Chem., 55, 231-242.

Al-Sabha, T.N.; Al-Hammoshi, H.M. (2013). Sensitive spectrophotometric method for determination of chloramphenicol in pharmaceutical preparations using 7,7',8,8' tetracyanoquinodimethane reagent. J. Edu. and Sci., 26, 43-53.

Al-Sabha, T.N.; Rasheed, B.A. (2010). Spectrophotometric method for determination of chloramphenicol in pharmaceutical preparations using 1,2-naphthoquinone-4-sulphonate as a chromogenic reagent. Jor. J. Chem., 5, 201-210.

Al-Shirifi, A.N.; Alhameedi, D.Y. (2016). New spectrophotometric method for the determination of chloramphenicol in pharmaceutical preparations based on Schiff base reaction with p-dimethylaminobenzaldehyde as reagent. Inter. J. Chem. Tech. Res., 9(5),712-722.

Al-Ward, H.S. (2012). Kinetic spectrophotometric methods for the determination of chloramphenicol in pharmaceutical preparations. J. Al-Nahrain University., 15, 22-30.

Bjorn, J.A. (2013). LC-MS residue analysis of antibiotics. PhD thesis, Wageningen University, Wageningen, pp. 25-26.

British Pharmacopeia on CD-ROM, (2013). "System Simulation Ltd The Stationary Office". $7^{\text {th }}$ ed., London.

Falagas, M.E.; Grammatikos, A.; Michalopoulos, A. (2008). Potential of old-generation antibiotics to address current need for new antibiotics. Expert. Rev. Anti Infect Ther., 6(5), 593-600.

Mallu, U.R.; Reddy, K.H.; Bobbarala, V.; Penumajji, S. (2011). Determination of beclomethasone dipropionate, clotrimazole, chloramphenicol and lidocaine in pharmaceutical formulations using a novel RP-HPLC method. Inter. J. Pharm. Bio. Sci., 2,452-462.

Hoang, V.D; Hue, N.T.; Tho, N.H.; Nguyen, H.T. (2015). Simultaneous determination of chloramphenicol, dexamethasone and naphazoline in ternary and quaternary mixtures by RP-HPLC, derivative and wavelet transforms of UV ratio spectra. Spectrochimica Acta Part A: Molec. Biomolec. Spec., 139, 20-27.

Sayhood, S.K.; Mohammed, J.H.; Jameel, S.S.; Khether, M.M.; Mutluk, A.S.; Abed-Alrahman, M.Z. (2013). Spectrophotometric determination of chloroamphenicol drug in pharmaceutical formulation using oxidative coupling reaction and colour measurement teqnique. Al-Kufa J. Chem. Sci., 7, 23-34. 
Sinan, R.M.; Al-Abachi, Q. (2010). Spectrophotometric determination of chloramphenicol in pharmaceutical preparations via oxidative coupling reaction with pyrocatechol. $A L-$ Mustansiriya J. Sci., 21(5), 281-287.

Suguna, P.; Sathyanarayana, B.; Naidu, N.V.S. (2016). Validated spectrophotometric method for the determination chloroamphenicol in pure and in its dosage form. Inter. J. Curr. Pharm. Res., 8(3), 22-27.

Suguna, P.; Naidu, N.V.S.; Sathyanarayana, B. (2014). Determination of chloramphenicol in bulk drug and pharmaceutical dosage forms by HPLC . IOSR J. Pharm., 4(12), 60-70.

Rocha, L.; Nicki, G.; Engeseth, J.; Fernandes, C.; Beatriz, M.; Gloria, A. (2015). LC-MS/MS determination of chloramphenicol in food of animal origin in Brazil. Sci. Chromatog., 7(4), 287-295.

Suliman, S. R.; Razzak, F. H. (2000). Determination of chloramphenicol in human serum and urine by differenatial - puls polarography. Raf J. Sci., 11(2), 8-13.

Wafi, A.; Supriyanto, G.; Tjahjandarie, T.S. (2015). A novel spectrophotometric method for determination of chloramphenicol based on diazotization reaction at room temperature. $J$. Chem. Pharm. Res., 7, 272-277.

Yafeng, Z.; Cai, L.; Cao, G. (2014). Determination of chloramphenicol by voltammetric method. J. Electrochem. Soc, 161(3), 129-132. 